\title{
Onde estaes Felicidade?
}

\author{
Where are you, Felicidade?
}

Maria Nilda de Carvalho Mota*

1 Doutoranda da área de Estudos Comparados de Literaturas de Língua Portuguesa da Faculdade de Filosofia, Letras e Ciências Humanas da Universidade de São Paulo. 


\section{lirismo e seus despejos \\ À Carolina Maria de Jesus}

De olhar vagaroso por entre os restos

do que fazemos de nossa carne

a mão lateja vasculha:

bilhetes, bocas cortadas

martelo de dar murro em ponta de náusea

salivas secas de um beijo mau dormido roncos de quem dorme pela palma aberta onde nem mesmo a linha do horizonte é sinal de folha beijada.

Por entre folhas de um vento ainda por cair é preciso refogar a peleja do dia na panela vazia cumprir a iluminação do dia na lua ainda por-vir enquanto a mão resvala úmida de ninar linhas em branco como quem se despede do cheiro que não é seu mas de outra mentira.

Ovos de abrigar formigas

que carregam na boca salivas do outono

retalhos de volúpias cansadas

bolor de tempo ancorado

lá vai Carolina recolhendo-se

para o mistério, inefável, da sobra.

Milton Melo

O poema O lirismo e seus despejos, de Milton Melo - o pouco conhecido "professor-poeta", como tantos e tantas, inspirado e apaixonado pela obra e figura 
de Carolina Maria de Jesus - serve de abertura ao seu mais recente livro Onde estaes Felicidade? (São Paulo, Edições Me Parió Revolução, 2014, 144p.).

Publicado em versão impressa, em parceria com o Ministério da Cultura, via Fundação Cultural Palmares, e o Ciclo Contínuo Editorial (tiragem de 2000 exemplares), e em versão virtual (com parceria entre as editoras Me Parió e Letraria), a obra teve distribuição gratuita e encontra-se disponível na $w e b^{1}$, embora, como era de se esperar, a versão impressa esteja praticamente esgotada.

Como Carolina, poucas escritoras têm o privilégio de serem lembradas um século depois de seu nascimento e, se pensarmos em escritoras negras, certamente o adjetivo "poucas" deverá ser substituído por "raras". Se fecharmos um pouquinho mais nosso foco e imaginarmos quantas vezes, na história do Brasil, uma mulher negra - e pobre - foi homenageada em seu centenário de nascimento, descobriremos que a "improvável" escritora Carolina Maria de Jesus prossegue estreando façanhas literárias - a primeira delas, como é de conhecimento público, foi o fato de o seu primeiro livro, Quarto de despejo (1960), publicado com ajuda do então jovem jornalista Audálio Dantas, ter se tornado imediatamente em um best seller, sendo traduzido para outros 13 idiomas.

Apesar do sucesso inicial, no entanto, Carolina não obteve o mesmo resultado em suas demais publicações, de modo que, ao fim da vida, terminou sendo praticamente esquecida pelo grande público, embora sua obra venha sendo cada vez mais objeto de interesse nos meios acadêmicos e literários - sobretudo dentro dos movimentos conhecidos como "periféricos" ou "marginais". Nestes, Carolina realiza mais uma façanha: a de ser reconhecida como precursora desses movimentos, cujo foco literário, centrado na vivência da população negra e pobre, favelada, encontra inspiração e força nos seus escritos.

Nesse sentido, Onde estaes Felicidade? chama a atenção já desde as primeiras páginas onde encontramos, precedendo o poema de Milton Melo, uma lista com mais de cinquenta nomes de pessoas (em geral admiradores e admiradoras da obra de Carolina, professores e professoras, escritores e escritoras, grupos culturais ligados à literatura periférica ou não) e algumas instituições que colaboraram com a publicação, muitas delas doando dinheiro para que a editora Me Parió Revolução - selo independente criado por mulheres da periferia de São Paulo, integrantes do grupo político-cultural Poder e Revolução, sem outros

1 Disponível no sítio <http://www.letraria.net/site/biblioteca/> 
recursos além seu próprio trabalho e capacidade de mobilização - viabilizasse a publicação. Ao que tudo indica, a participação e o apoio de tantas pessoas confirmam o desejo pela obra caroliniana e apontam para sua importância na literatura brasileira.

Em seguida ao poema, temos o prefácio de Raffaella Fernandez - pesquisadora e co-organizadora do livro. Além de apresentar um pequeno resumo sobre os textos de autoria de Carolina ora publicados, Fernandez explicita um importante aspecto que salta aos olhos durante a leitura da obra:

Para esta publicação, com apoio de Vera Eunice Lima de Jesus, fizemos a opção de fixar a sintaxe e a ortografia de Carolina de Jesus, evitando ao máximo as interferências e compilações que viessem a prejudicar a dicção bastante característica da escritora, como o sotaque mineiro audível nas palavras, a partir da grafia, por exemplo, de "dispunivel", "dicidi", "difunto" presentes na narrativa de "Favela" ou "póude", "vistir o vistido de viludo", "Ponhe" "Baruião" em "Onde estaes Felicidade?". Assim como na linguagem, muito característica de uma época, tanto quanto na reprodução da fala da vizinha "Pois sim!", percebe-se a interessante mescla da linguagem culta e da popular, característica de sua poética de resíduos, possibilitando a visibilidade de uma "norma" oculta da língua, inaugurada pela escritora de raízes negras em sua condição de favelada. (FERNANDEZ, 2014 apud JESUS, 2014, p.18).

Se por um lado a escolha pela manutenção da sintaxe e ortografia de Carolina (que podem ser visualizadas na versão virtual, pois esta contém imagens de manuscritos) mantém a sua dicção própria e tende a salvaguardá-la das dúvidas quanto à sua verdadeira autoria, dúvidas, maldosamente, a acompanharam durante muito tempo devido às sucessivas interferências editoriais em seus textos publicados. Por outro ângulo, a escolha tende a expor as hesitações características do processo de construção literária e incorreções ortográficas que a própria autora - empenhada que era em fazer e demonstrar o melhor de si -, se pudesse ser consultada a respeito, muito provavelmente quereria esconder ou corrigir.

Logo após o prefácio, chegamos, então, ao ponto mais esperado dessa publicação: o conto que empresta o nome ao livro Onde estaes Felicidade? e a narrativa autobiográfica Favela.

Ainda segundo Fernandez: 
A escolha destes dois textos inéditos que ora se publica se deu pelo fato de, neles, podermos acompanhar a versatilidade dessa escritora, que vai desde o testemunho embotado de um drama real ao gênero conto, carregado do lirismo e da beleza que Carolina de Jesus buscou em sua trajetória quixotesca de devires criativos, como figurinista, dramaturga, romancista, poeta, diarista, musicista e atriz. Quando reescreve seu conto “Onde estaes Felicidade?", ela não economiza nos processos elaborativos, fixados desde as correções e hesitações sobre a pontuação, a escolha das palavras, até as duas linhas narrativas: a do marido apaixonado e a do sedutor caixeiro-viajante, atando a personagem da mocinha deslumbrada com os progressos da cidade ao nó da narração. Carolina de Jesus trabalha com perspicácia o desfecho, construído a partir de um trocadilho com a palavra "felicidade", nome próprio e nome comum. Esse texto é substancializado pela estrutura da fábula, isto é, tem um conselho a dar. No caso, a lamentável troca das ilusões do consumo e das ambições humanas em detrimento do verdadeiro amor. (FERNANDEZ, 2014 apud JESUS, 2014, p.15).

O segundo texto autoral, Favela, segue a linha de outros relatos seus já publicados e nos dá conta da chegada de Carolina à cidade de São Paulo, suas tentativas de estabelecer-se em empregos precários de empregada doméstica e sua fixação de residência na nascente Favela Canindé, às margens do Rio Tietê, onde morou até 1960, ano em que publicara seu Quarto de Despejo.

Embora relativamente curtos, pois ocupam cerca de 60 das 144 páginas do livro, os textos Onde estaes Felicidade? e Favela alcançam pelo menos dois pontos necessários e urgentes: trazer de volta à cena literária essa escritora e dar a conhecer ao grande público sua faceta menos testemunhal. Nesse sentido, o fato de ser uma obra com distribuição gratuita e livre acesso na web amplia contundentemente as chances de que isso de fato ocorra.

Após os escritos autorais, na seção Ensaios sobre Carolina, lê-se um conjunto de sete textos (seis na versão impressa), formando um pequeno dossiê sobre a vida e obra de Carolina, escritos pela escritora Miriam Alves, pelo pesquisador Sergio Barcellos (Pós-doutor em Estudos de Escritas de Vida pela Hofstra University), as pesquisadoras Fernanda de Oliveira Matos (Universidad de Chile) e Flávia Rios (Universidade de São Paulo), além das "carolinas" Geny Ferreira Guimarães e Hildália Fernandes Cunha Cordeiro, estas últimas, representantes do coletivo de mulheres Carolinas ao Vento. 
Por fim, tem-se o pequeno ensaio fotográfico Favela, 2014, de Sandrinha Alberti, no qual é possível reconhecer um contraponto entre a favela (quase rural) narrada por Carolina e as atuais - onde se destacam a falta de espaços, ainda a ausência de saneamento básico e as condições de moradia também muito precárias. Entretanto, curiosamente, percebemos que - exceto pela presença da polícia - como na extinta Favela Canindé, nas favelas atuais o Estado permanece ausente, mas o Mercado não. Este, ao perceber que esses locais abrigam uma imensa massa de trabalhadores e trabalhadoras, "carolinos" e "carolinas" adianta-se e instala-se. Assim, às margens dos esgotos a céu aberto, sobram embalagens descartáveis e televisores a cabo, como se pode perceber pelo lixo acumulado e pelas antenas cravadas nas paredes de alvenaria sem reboco.

\section{Referências}

JESUS, Carolina Maria de. Onde estaes Felicidade?. São Paulo: Edições Me Parió Revolução, 2014. 